\title{
Foreign Trade, Human Capital and Economic Growth: An Empirical Approach for the EU Countries.
}

\begin{abstract}
While neoclassical growth theory does not consider external demand to be a constraint to growth, the Keynesian approach emphasizes that demand forces are actually the key factors determining growth. In this paper an attempt is made to introduce the balance-of-payments constraint hypothesis into the neoclassical growth model through a consideration of a sample of 14 EU countries over the period 19802004.

A panel data model is estimated using different proxies for human capital and foreign trade as conditioning factors to explain growth. The income-elasticity ratio with respect to exports and imports and the degree of openness are also used to capture the effects of (non-price) competitiveness and trade intensification on growth.

The regression analysis shows that the inclusion of human capital, external trade and interaction terms between them have significant effects on growth. Depending on the combination of variables used, the constraining factor to growth can be shown to be due to foreign trade, human capital or both.
\end{abstract}

JEL code: $\mathrm{C} 23, \mathrm{~F} 43, \mathrm{O} 47$

Keywords: growth; human capital; trade competitiveness; income-elasticities of foreign trade; balance-of-payments constraint 


\section{Introduction}

The role of international trade in a country's growth performance has been widely discussed by economists, trying to explain the different paths of economic growth observed for several industrialized countries from the 1950s onwards.

It is possible to distinguish two main theories explaining the international trade impact on economic growth, namely the supply-orientated approach associated with the neoclassical theory of growth and the demand-orientated approach associated with the Keynesian perspective. The former does not offer a formal theory for the possible impact of a country's balance-of-payments on its growth performance, but the general idea is that the accumulation of inputs (especially of capital) is the only way through which an economy can expand. When balance-of-payments problems occur, prices adjust automatically to restore equilibrium. Opposing this supply-orientated approach is the Keynesian view, which states that demand (especially external demand) guides the economic system and that supply, within certain limits, simply adapts to it. Demand is able to generate its own supply by encouraging investment, absorbing underemployment and raising productivity growth. The well-known export-led growth hypothesis ${ }^{1}$ associated with "Thirlwall's law" is part of this demand-orientated approach, and it supports the notion that exports are the engine of growth. The denominated new theory of endogenous growth, which attributes a special role to human capital, aims to reduce the differences between the two main views. However it essentially remains a supply-orientated approach and most importantly, it does not take into account the fact that growth can be constrained by external demand. ${ }^{2}$

\footnotetext{
1 Thirlwall (1979), Bairam (1988), Marin (1992), Muscatelli et al. (1994), Atesoglu (1995) and McCombie (1997) are some of the studies that have been carried out on the issue of export-led growth. ${ }^{2}$ Although Romer (1986) and Lucas (1988) point out the positive effects of international trade on growth, Rodriguez and Rodrik (2000) question the sign and the significance of such impact.
} 
Recent studies by Santos- Paulino and Thirlwall (2004), Pacheco-López and Thirlwall (2006), Vera (2006), Porcile et al. (2007), among others, make clear how balance-ofpayments problems can constrain growth in developing countries as a result of trade liberalization. Some examples for particular EU countries are those from Léon-Ledesma (1999) for Spain, Kvedaras (2006) for the Central and Eastern European countries (CEE), Garcimartín et al.(2008) for Ireland and Antunes and Soukiazis (2009) for Portugal. In these studies, it is shown that actual growth can accurately be predicted by the balance-of-payments equilibrium growth rate given by "Thirlwall's law". However, all these studies are strictly demand-orientated with growth being determined by demand forces (especially external demand) and supply adjusting to the demand requirements.

The aim of this paper is to include demand and supply forces into the same growth model. To do that we introduce factors related to external trade and external demand into the supply-driven growth model and we test empirically their relevance on growth. The above variables can be combined with different proxies for human capital and alternative interaction terms can be employed to check their validity on growth. In doing so, we try to specify a more complete growth equation that explicitly takes into account the strength of external demand and investigate how the latter interacts with different levels of human capital and foreign trade variables. These are the main aspects that distinguish this paper from previous studies. As far as we know, Barro's type growth models have not previously taken the balance-of-payments constraint hypothesis into consideration.

Our empirical analysis estimates the growth equations by considering a sample of 14 EU countries over the period 1980-2004, using panel data regressions. The variables to express foreign trade are the degree of openness and the net foreign balance (as a 
percentage of GDP). Additionally, the income-elasticity ratio of foreign trade (measuring non-price competitiveness) is used as the key factor of the balance-ofpayments constraint hypothesis derived from the well-known "Thirlwall's law".

The variables related to human capital are: the average years of schooling of the adult population, which represents basic levels of human capital qualifications; the publication rate, which measures the efficiency of human capital reflecting scientific production; the patents rate as an approximation for innovation and R\&D activities; and the combined patents/articles ratio, which aims to measure the ability of transforming scientific production into innovation.

The paper is organized as follows: following the Introduction, Section 2 explains the theoretical aspects of the model to estimate and discusses the relevance of human capital, foreign trade and external demand on growth. Some statistical data on international trade performance, human capital differences between countries and the variables used in the estimation approach are explained in Section 3. The empirical results obtained from the panel data regressions are analysed and discussed in Section 4. The final section concludes the main findings of this study.

\section{Theoretical aspects of the model}

The model used in the empirical approach is based on the conditional convergence hypothesis developed and tested empirically by Barro and Sala-i-Martin (2004). The model is an extension of the Solow's (1956) growth model with human capital and technical progress endogenously determined and increasing returns to scale stemming from both to compensate for the diminishing returns of physical capital that were assumed in the neoclassical theory. The model predicts conditional convergence in per capita income or product per head among economies when differences in the steadystates are controlled for. Human and physical capital along with technical progress and 
innovation are found to be some of the most important determinants of growth. Economies converge to different steady-states of per capita income which are characterized by the above conditioning factors.

The convergence issue is particularly important at the EU level, given the increasing integration and the goals of social and economic cohesion. Most studies agree with the evidence of higher convergence during the 1960s, stagnation during the $1980 \mathrm{~s}^{3}$ and an increase in disparities in the 1990s within the EU. Sala-i-Martin (2003) referred to this as a sign of failure to achieve higher cohesion in Europe.

Our study contributes to the large literature on convergence in the EU. We find evidence of convergence when human capital and foreign trade are taken into account in the growth equation. In addition, the inclusion of interaction terms highlights the importance of considering joint effects of human capital and foreign trade and the existence of technological diffusion stimulated by trade.

\section{The role of human capital and technology on growth}

Endogenous growth models can be grouped in two main streams: the first is closer to the neoclassical perspective, and gives emphasis to the accumulation of a broader concept of capital which is not subject to decreasing returns. The second underlines the endogenous development of knowledge or R\&D as the key factors of growth (Aghion and Howitt, 1998; Turnovsky, 2001).

In the first group of models, a broader version of capital, including both physical and human capital, is considered as input into the production function (Lucas, 1988; Mankiw et al., 1992). In this context, human capital is regarded as a measure of the ability and skills of a labour force and it is evaluated by the formal education or the job

\footnotetext{
3 Button and Pentecost (1993) blame the Exchange Rate Mechanism for the reduction of the speed of convergence among the EU members during the 1980s. Borota and Kutan (2008) offer an overview on the convergence issue across the EU, arguing that economic integration had positive growth effects in Europe.
} 
learning accumulated experience. The common finding is that most models demonstrate the existence of a positive correlation between human capital accumulation and growth.

The second group is made up of models that focus on the importance of technological change as the engine of growth (Romer, 1986). In these studies, human capital plays a relevant role in enabling innovation and R\&D activities in developed countries. In less developed countries, human capital is important for assimilating new technologies developed by advanced countries and transferred through trade. In this context, human capital is a crucial factor in the "social capability" of countries to adopt foreign technology (Abramovitz, 1986; Benhabib and Spiegel, 2003).

Although, in principle, a better-educated and well-trained workforce can be expected to exert a positive effect on growth, ${ }^{4}$ results have sometimes shown a different pattern, with the impact of human capital on growth being negative and/or statistically insignificant, especially in panel data studies. The explanation for such an unexpected result can be the use of poor quality data and inadequate proxies to capture qualitative rather than quantitative aspects of human capital (Islam, 1995).

Our paper uses four main variables to measure the different levels of human capital: the average years of schooling, which reflects the basic qualifications of human capital; the publication rate, which measures the efficiency of human capital and reflects scientific production; the patents rate as an approximation for innovation and R\&D activities; and the combined patents/articles ratio, which aims to measure the ability to transform scientific production into innovation. It is to be expected that higher levels of human capital related to scientific production and innovation differentiate the steadystates of the EU countries in the growth equation more properly.

\footnotetext{
${ }^{4}$ For studies on the positive impact of human capital on income, see Söderbom and Teal (2003) and Ciccone and Papaioannou (2006).
} 


\section{The balance-of-payments constrained growth rate}

Both the neoclassical and the endogenous growth theories concentrate on the supply side of the economy. After specifying the functional form of the aggregate production function, the growth of output is explained by the growth of certain input factors such as labour, a broader concept of capital and total factor productivity. Although, according to this approach, different growth rates can be explained by differences in factor supplies and productivity, it is not clear why the growth of factor supplies may vary between countries. Furthermore, with this approach, relative price adjustments and exchange rate flexibility can bring the economy back to equilibrium when foreign trade imbalances occur. No special role is attributed to trade and most importantly, growth is not constrained by external demand.

Within the framework of the demand-orientated approach, where income adjusts to preserve equilibrium, stands Thirlwall's "fundamental law". Thirlwall (1979) developed an export-led growth model where the performance of the balance-of-payments (on current account) matters for the long-term growth. According to Thirlwall, an unsustained balance-of-payments deficit can constrain domestic demand and retard growth. He established a simple rule that determines the rate of growth of domestic output as being consistent with the balance-of-payments equilibrium. This rule (known as "Thirlwall's law") states that a country's balance-of-payments equilibrium growth rate is given by the ratio of exports growth $(x)$ over the income-elasticity of demand for imports $(\pi)$, assuming that relative prices remain constant in the long-term. ${ }^{5}$ Thirlwall's rule can be expressed in the following way:

$$
y_{B P, t}=\frac{\varepsilon(z)_{t}}{\pi} \quad \text { (1a) } \quad \text { or } \quad y_{B P, t}=\frac{x_{t}}{\pi}
$$

5 This hypothesis is reasonable for the EU countries with free trade and towards a fixed exchange rate over the period considered aiming to adopt a single currency by 1999. 
Equation (1a) determines the rate of growth of domestic income consistent with the balance-of-payments equilibrium (on current account), denoted by $y_{B P, t}$. This relation stresses both the positive impact of increasing external demand $\left(z_{t}\right)$ and the inverse impact of higher import penetration $(\pi)$ on the growth of domestic income. Equation (1b) is known as "Thirlwall's law" or the dynamic Harrod's foreign trade multiplier obtained by assuming that $x_{t}=\varepsilon(z)_{t}$ when relative prices remain constant. Equation (1a) can also be written as:

$$
\frac{y_{B P, t}}{z_{t}}=\frac{\varepsilon}{\pi}
$$

This new expression determines a country's relative growth rate with respect to the rest of the world (or a group of other countries) and is given by the ratio of its incomeelasticity of demand for exports relative to its income-elasticity of demand for imports. This is an interesting relation predicting that a country will experience faster growth than the rest of the world $\left.\left(y_{B P, t}\right\rangle z_{t}\right)$ as long as its income-elasticity of demand for exports is greater than its income-elasticity of demand for imports $(\varepsilon>\pi)$. This is an important condition for a country to grow faster without deteriorating its balance-ofpayments performance. Therefore, the ratio of the income-elasticity of foreign trade $(\varepsilon / \pi)^{6}$ can be seen as reflecting the balance-of-payments constraint hypothesis. Considering the case where $\pi>\varepsilon$, signifying that imports penetration in domestic market is higher than exports penetration in external markets, "Thirlwall's law" predicts that the country will be constrained by external demand in the long-term and will thus grow at a lower rate than the rest of the world.

6 The income-elasticity ratio with respect to exports $(\varepsilon)$ and imports $(\pi)$ measures the non-price characteristics of the goods produced and traded associated to quality, design, durability, confidence, innovation, marketing and sales efficiency. These are known as the supply characteristics. 
In this paper, apart from the balance-of-payments constraint factor $(\varepsilon / \pi)$, some other aspects related to trade will also be considered in the growth equation. These include the degree of openness, which has great relevance to the EU countries in expressing trade intensification, and the net foreign balance, which expresses trade competitiveness.

Indirect effects of international trade have also been found in the empirical literature, which explain the channels through which trade affects growth. Levine and Renelt (1991) provide evidence that free international trade affects growth indirectly through investment. Owen (1999) asserts that openness has a positive effect on enrolment ratios in countries with lower human capital stocks. Harrison (1991) argues that trade policy affects growth through its impact on technological change. Scale economies, comparative advantages, availability of intermediate products and capital equipment, exchange of information and knowledge, new production and organisational methods and technological diffusion are all referred to as additional channels to growth through trade (Grossman and Helpman, 1991; Di Liberto, 2005).

\section{Historical evidence and the variables used in the model}

Our sample consists of a set of 14 EU members ${ }^{7}$ and covers the time span from 1980 to 2004. The reason for selecting this particular sample is to ascertain whether the balance-of-payments constraint hypothesis (through the income-elasticities of external trade) and the degree of openness are important determinants of growth for this set of countries, characterized by a high degree of economic integration implying free trade, free factor mobility and the adoption of common policies. It is argued that capital transfers will solve the problem of payments of external imbalances due to highly integrated capital markets, and that there is no need for foreign currency reserves to pay

7 The set is made up by Austria, Belgium, Denmark, Finland, France, Germany, Greece, Ireland, Italy, the Netherlands, Portugal, Spain, Sweden and the UK. 
external transactions within the Union. However, according to the demand-orientated approach, balance-of-payments problems are structural in nature, associated with nonprice competitiveness. Persistent trade imbalances will affect the long-term economic performance, retard growth and increase unemployment. This is the essence of the balance-of-payments constraint hypothesis, which we introduce into the growth equation (expressed by the income-elasticity ratio of exports relative to imports $(\varepsilon / \pi)$ ) to test its impact on growth. ${ }^{8}$

As our interest lies on measuring the impact of foreign trade on growth, it is convenient to analyse the differences among countries in terms of the degree of openness (defined as the ratio of external trade to GDP) and the net foreign balance (the share of net trade to GDP) ${ }^{9}$ over this period. This historical evidence is given in Table 1 and illustrated in Charts $\mathbf{1}$ and 2, respectively.

\section{[Insert Table 1 around here]}

\section{[Insert Chart 1 around here]}

As we can see in Table 1, the degree of openness in all fourteen countries increased substantially from 1980 to 2004 as a result of trade intensification. Ranking the countries in descending order for 1980, the highest rates are those of Belgium (104.4), the Netherlands (77.7), Ireland (65.1) and Austria (57.5). Only Belgium shows a ratio higher than $100 \%$. The top-down countries are France, Italy, Greece and Spain (all bellow 32\%). In 2004 Ireland appears in first place (176.7), followed by Belgium (174.0), the Netherlands (146.9) and Austria (103.0) - all with ratios higher than $100 \%$. The less open economies are at this time the UK, France, Italy and Greece, all with ratios lower than $60 \%$. The biggest changes in the degree of openness between 1980 and 2004 occurred, in descending order, in Spain, Ireland, Germany and Portugal and the

\footnotetext{
${ }^{8}$ A detailed description of the variables and data sources is provided in the Appendix.

9 The terms net foreign balance and net foreign trade will be used alternatively and refer to net exports of goods and services.
} 
less pronounced increases were those of Italy, Austria, the UK and Belgium. The degree of openness of the EU average doubled within the period, from $47 \%$ to $94 \%$.

\section{[Insert Chart 2 around here]}

As for net foreign balance, only four countries registered a surplus in 1980 - the UK, Denmark, Spain and Italy. In contrast, in 2004 eight countries registered a positive net trade i.e. Ireland, Sweden, Finland, the Netherlands, Denmark, Germany, Belgium and Austria. On the other hand, Italy and France reported a negative, although close to zero, net trade. It can also be seen that trade performance in Greece, Italy, Portugal, Spain and the UK deteriorated during the period under study. This is an interesting result showing that the southern countries of the EU, being less competitive, did not benefit much from the free single market. As we already know, large transfers in the form of structural funds were employed to compensate for this. In the UK, the explanation also lies on competitiveness and structural problems regarding the balance-of-payments performance. ${ }^{10}$ As a whole, the EU average went from a deficit in 1980 to a surplus of $2 \%$ in 2004 . Thus, during the period between 1980 and 2004 some relevant changes have occurred both in the degree of openness and the balance of trade in the core of the EU countries. These changes need to be taken into account in the growth process.

In Chart 3 we can see how the income-elasticity ratio with respect to exports and imports $(\varepsilon / \pi)$ performed over the five-year intervals, between 1976 and 2004.

\section{[Insert Chart 3 around here]}

As it can be seen, Ireland is the only country in which the ratio is always greater than one, showing that exports penetration is higher in foreign markets than imports penetration in the domestic market. Another consequence of this high ratio is that the products produced and traded in this country are competitive both in foreign and

\footnotetext{
${ }^{10}$ For a detailed analysis of the balance-of-payments problems in the UK, see Thirlwall and Gibson (1992).
} 
domestic markets. According to "Thirlwall's law", Ireland has the advantage of being able to grow relatively faster without incurring balance-of-payments problems. The experience of the other countries is mixed, with the income-elasticity ratio varying between countries and over the periods of time considered. In general, the higher the income-elasticity ratio of foreign trade the higher the country's growth rate is expected to be. With a privileged value higher than one, a country has the ability to grow faster than other trade partners.

Moreover, we can see from Chart 3 that there are five results showing negative income-elasticity ratios, which contradict the conventional trade theory. These cases can be explained by considering various special circumstances that were apparent in some countries during particular periods of time. For example, Finland (1991-1995) lost its principal trade partner due to the collapse of the former USSR; Germany (1991-1995) faced the costs of the unification process; Greece (1981-1985) had adaptation problems in the first years of its adhesion to the former EEC because of its low competitiveness; Italy (2001-2004) suffered lack of growth and political instability; and Portugal (19811985) faced the severe problem of external debt payment and the restrictive measures imposed on it by the IMF in that period. All of these situations seriously affected external competitiveness, creating balance-of-payments problems that reflected in the poor growth performances of these countries in these periods.

Differences on human capital performance are also significant between the European countries. Four proxies were used to account for different levels of human capital: the average years of education of the population aged 25-64 (educ), ${ }^{11}$ which aims to encompass the basic level of education; the articles ratio (art) defined as the number of articles published per country's million inhabitants aged 25 or over, which represents a

11 This indicator is a direct measure of the stock of human capital (Islam, 1995). However, it is limited in the sense that it does not allow us to understand the efficiency of human capital in a broader sense. 
proxy for scientific production; the patents ratio (pat) defined as the number of patents per country's million inhabitants aged 25 or over, which aims to encompass higher levels of human capital associated with research and development activities; and a combined ratio (pat/art) revealing a country's ability to transform scientific research into innovation (Soukiazis and Cravo, 2008). All these statistics on human capital are shown in Table 2. As it can be seen, average years of education have been improved in all countries, but Portugal, Spain and Italy still remain behind the others. The same tendency is apparent regarding scientific production (measured by articles publication) and innovation activities (patent ratio), where the Southern countries show again relatively lower levels on these measures of human capital. A less expressive result is on the patents/articles ratio which remained on average constant over the period between 1980 and 2004, with the majority of countries showing a decline in this indicator.

\section{[Insert Table 2 around here]}

These preliminary findings regarding foreign trade and human capital performances justify our interest in measuring the impact of these variables on economic growth. For this purpose, a general specification of the "Barro growth regression" was employed. This regression relates the growth of per capita income to a set of explanatory variables that includes: the lagged level of per capita income (the convergence factor); the annual growth rate of population $n$; the investment ratio $s$; the different levels of human capital $H C$; and measures related to foreign trade $F T$.

Taking into consideration the discussion presented in the previous section regarding the role of human capital and foreign trade on growth, we expect them to have a positive impact. The annual population growth rate is expected to have a negative impact on economic growth, because the available capital must be spread more thinly 
over the population of working age. ${ }^{12}$ Physical capital is believed to influence the rate of growth of output positively, due either to its impact on the steady-state level of output per capita and hence on the growth of output - the neoclassical view - or to spillover effects and economies of scale - the endogenous growth approach (Economidou et al., 2006).

The inclusion of the income-elasticity ratio in the growth regression represents an attempt to insert the export-led growth hypothesis of the demand-orientated approach into the endogenous supply-driven growth model. It is expected that this ratio will have a positive effect on growth, as the increase in the ratio, due to a higher income-elasticity of the demand for exports $(\varepsilon)$ relatively to the income-elasticity of the demand for imports $(\pi)$, puts an economy in a more favourable position with the rest of the world in terms of competitiveness. Finally, interaction terms are also included in the growth regression. ${ }^{13}$ Several hypotheses were alternatively tested, i.e. the interaction between foreign trade and human capital variables or between the income-elasticity ratio and the foreign trade measures or the human capital proxies. No viable results emerged, however, from the later. If the $(\varepsilon / \pi)$ ratio appears as an important factor in the growth equation for the set of the EU countries under study (either isolated or combined with other variables), then we may infer that the balance-of-payments constraint hypothesis of the demand-orientated approach is relevant in the endogenous growth model. The empirical analysis is based on panel data regressions described in the following section.

\section{Empirical evidence from growth regressions}

The dynamic panel data specification is the most suitable approach for analysing growth dynamics while taking into account country-specific effects. The estimation

\footnotetext{
12 For this argument see Mankiw at al (1992).

${ }^{13}$ The exogeneity of interaction terms was tested by the use of the Difference-in-Hansen test.
} 
method most commonly applied to dynamic equations with panel data and a lagged dependent variable is the GMM (Generalised Method of Moments), which uses a set of instrumental variables to solve the problem of the endogeneity of the regressors. Both types of GMM estimators (the difference and the system GMM) can be considered in the regressions, in both their one-step and two-step versions. The set of instruments of the difference GMM estimator includes all available lags of the levels of endogenous variables and strictly exogenous regressors (Arellano and Bond, 1991; Baum, 2006). The system GMM estimator considers not only the instruments from the difference GMM estimator, but also the first lagged difference of the explanatory variables in levels (Arellano and Bover, 1995; Blundell and Bond, 1998).

In this study, proper results were found using either the difference GMM or the system GMM, with the former method appearing more frequently in the tables. The reason for this could be the relatively short panel employed: in this case, the use of lagged levels as instruments enables the maximization of the sample size. The reported results are the most efficient ones obtained and those that passed the diagnostic tests of over-identification and absence of second order serial correlation of error terms. In the meantime we report the number of instruments used in all estimations. Wherever it was necessary, the length of lags was reduced and the instruments were collapsed, thus reducing the size of the instruments matrix. In small samples the collapse option is extremely useful because it prevents the number of instruments from exceeding the number of units (countries) and the consequent bias that emerges from there (Roodman, 2006). 
In our empirical analysis we consider the growth model as was adapted by Caselli et al. (1996) to panel data to avoid omitted variable bias. The general specification of the growth equation (with no interaction terms) is as follows: ${ }^{14}$

$$
g y_{i, t}=b \ln \left(y_{i, t-5}\right)+c_{1} \ln \left(n_{i, t}+g+\delta\right)+c_{2} \ln \left(s_{i, t}\right)+c_{3} \ln \left(H C_{i, t}\right)+c_{4} \ln \left(F T_{i, t}\right)+v_{i, t}
$$

where $v_{i, t}=\alpha_{i}+u_{i, t}$

In this equation, $\alpha_{i}$ refers to country-specific effects such as differences in the initial level of efficiency or country-specific measurement errors (Bond et al., 2001) and $u_{i, t}$ is the idiosyncratic error term. The subscript $i$ refers to countries $(i=1, \ldots, 14)$ and $t$ to time $(\mathrm{t}=1985, \ldots, 2004)$. Yearly time intervals are considered too short for studying growth, since short-term disturbances may appear large in short-term intervals (Islam, 1995). We thus opted for five-year time-intervals, benefiting from the fact that error terms can be less correlated than would be the case with yearly data. ${ }^{15}$

The dependent variable is the annual growth rate of per capita income at five-year intervals. The growth regressions can be adapted to take into account each of the four human capital proxies separately, combining them alternatively with the international trade variables. Following this approach, the most plausible outcomes are shown in Table 3. The proxies for human capital $(H C)$ used are the average years of schooling of the adult population $(e d u c)$, the articles ratio (art), the patents ratio (pat) and the patents/articles ratio (pat/art). As foreign trade variables, we have the degree of openness $(o p)$, the net foreign balance $(n f b)^{16}$ and the income-elasticity ratio of exports to imports $(\varepsilon / \pi)$. The latter reflects non-price competitiveness and illustrates the strength of demand on growth.

\footnotetext{
14 The regressions were run by Stata.

15 There are several growth studies based on five-year intervals, among them those of Islam (1995), Caselli et al. (1996), Söderbom and Teal (2003) and Economidou et al. (2006).

${ }^{16}$ No significant results were obtained from its inclusion in the regression.
} 
As a preliminary note, we wish to clarify that the lagged per capita income $\left(y_{i, t-5}\right)$, the annual growth rate of population $\left(n_{i, t}\right)^{17}$ and the investment ratio $\left(s_{i, t}\right)$ are common to all of the growth regressions that we ran. As for the remaining variables, we tested their relevance assuming alternative combinations between the human capital and foreign trade proxies.

\section{[Insert Table 3 around here]}

In column 1 of Table 3, the combination of the patents/articles ratio (measuring the ability to transform scientific work into innovation) with the degree of openness appears to explain satisfactorily the growth process of the EU economies. Both factors have positive and statistically significant impacts on the growth of per capita income as might be expected. Our results thus show that higher trade intensification and increased innovation capability are beneficial in inducing higher economic growth in the EU countries under study. As for the innovation proxy, our results confirm the idea that higher levels of human capital are more appropriate in differentiating the steady-states of countries with higher levels of development. On the other hand, the coefficient of the lagged per capita income is negative, which confirms the hypothesis of conditional convergence and the impact of the investment ratio on the growth equations is positive as expected, both being statistically significant at the $1 \%$ level.

Moreover, in terms of statistical significance, no other human capital proxy performed better when combined with the openness variable. However, when human capital was removed from the regressions the results improved: all coefficients had the expected signs and were statistically significant (independently of the GMM approach used). It was not possible to combine the net foreign balance with any of the four human capital proxies in the growth regression (in any of the four versions of the GMM

${ }_{17}$ To the annual population growth rate $n_{i, t}$ we added $(g+\delta)=0.05$, with $g$ the rate of technological progress and $\delta$ the rate of (human and physical) capital depreciation, equal across countries and through time. For more details on this issue, see Islam (1995). 
method), but in each case, when human capital was excluded, the results improved and the remaining coefficients had their expected signs and were statistically significant. ${ }^{18}$

The growth regression in column 2, includes the average years of education $(e d u c)$, the degree of openness (op), and an exogenous interaction term between them. The impact of human capital on growth is positive as long as the degree of openness is higher than $31.8 \% .{ }^{19}$ Countries that fall behind this cut-off point need to take precautions regarding economic growth. Conversely, the impact of openness is only positive if the average years of education is higher than 6.6. These conclusions derived from the interaction between the level of education and trade intensification seem to support the idea of knowledge and technology diffusion, arguing that technology transferred through trade can only be absorbed and developed through higher levels of education.

The knowledge/technology diffusion hypothesis is also supported in column 3 , where higher levels of human capital efficiency, expressed by the patents/articles ratio and the degree of openness, are considered. Both factors have a positive impact on growth as expected and are statistically significant (the patents/article ratio only at $10 \%$ level). Reasonable results were also obtained from the interaction between the incomeelasticity ratio $(\varepsilon / \pi)$ and the openness factor. This specification was supposed to investigate whether the impact of foreign trade on growth depends on an economy's relative position regarding (non-price) competitiveness towards the rest of the world and vice-versa. Our evidence suggests that the impact of the income-elasticity ratio on growth is expected to be positive whenever the trade intensity ratio is higher than $38 \%$. In fact, trade intensification and economic competitiveness are important determinants for growth.

\footnotetext{
${ }^{18}$ These results are not given here but are available from the authors on request.

19 The cut-off point is given by: $\exp (0.5272 / 0.1524)=\exp (3.459)=31.8$.
} 
Table 4 shows alternative panel regressions using exogenous interaction terms whose results become reasonable after removing the variables with coefficients displaying no statistical significance.

\section{[Insert Table 4 around here]}

The two first columns of Table 4 display the results of the combination of the patents ratio with the degree of openness and the corresponding interaction term. As foreign trade does not appear individually significant it was removed from the growth regression and the results improved. Once more, the interaction between trade intensification and higher levels of human capital associated to innovation appear to be relevant to growth. The general conclusions are similar, whether the two-step system (column 1) or the one-step difference GMM (column 2) is employed. In the former, the impact of innovation activities on growth is expected to be positive as long as the degree of openness is higher than $51 \%$ while in the latter case, the threshold rate goes up to $59 \%$. This evidence suggests a kind of interrelation between trade and innovation that significantly affects the pattern of growth.

Columns 3 and 4 of Table 4 show that when trade (through openness) is linked with even higher levels of human capital, given by the patents/articles ratio, the results are more reasonable. The difference between the two regressions lies in the estimation method (the two-step system in column 3 and the two-step difference in column 4). In both cases the impact of openness on growth is always positive, because the condition on the patents/articles ratio is always attained. Furthermore, the impact of foreign trade on growth of the EU countries during the period considered is always as desired because human capital does not constitute a limitation to obtaining the benefits from international trade. This is an interesting result suggesting an important link between the efficiency of innovation, trade and economic growth. 
The two last columns of Table 4 give significant evidence of the link between trade (through openness) and non-price competitiveness, which is given by the ratio of the income-elasticity of exports and imports. We can see that the impact of the incomeelasticity ratio on growth is positive whenever the degree of openness is above $56 \%$ (column 5) or above 51\% (column 6). This is also an interesting result which indicates the importance of competitiveness to growth when trade intensification occurs. The income-elasticity ratio measures the non-price competitiveness and is a crucial parameter in export-led growth and the balance-of-payments constraint hypotheses. Our results highlight the relevance of these factors to growth.

Generally, the panel data regression analysis suggests that when human capital is combined or interacted with foreign trade (especially openness) the result is positive on growth as long as a minimum threshold level is attained. There is a connection between human capital qualifications and trade performance. Another issue arising from the regression analysis is that balance-of-payments problems, which are reflected in low competitiveness, may be harmful to growth and this effect depends on the degree of openness.

\section{Final conclusions}

We have argued in this paper that the neoclassical approach to growth does not attribute a special role to foreign trade. Moreover, and most importantly, that the supplyorientated view, which includes both the neoclassical and endogenous growth approaches, does not take into account the fact that foreign trade imbalances might constrain domestic demand and retard growth. Price flexibility will bring the economy back to equilibrium whenever a shock occurs. Although the endogenous growth theory recognises the importance of trade, especially through the process of technological transfer and diffusion, it still remains a supply-orientated approach not giving an 
important consideration to the external demand as a possible constraint to growth. On the other hand, the demand-orientated approach, through the export-led growth and the balance-of-payments constraint hypotheses, highlights the importance of external demand as the key factor to domestic growth and the foreign trade imbalances as a serious impediment to growth.

In this paper an attempt has been made to reconcile these two views by introducing factors related to foreign trade into the growth model. Their relevance was explicitly tested using the balance-of-payments constraint hypothesis. A more complete model of growth was estimated using different proxies for human capital and foreign trade to differentiate the EU countries more efficiently. Interaction terms were also used to detect important links between human capital and foreign trade, and also between (nonprice) competitiveness and trade intensification.

The empirical analysis estimates growth equations by using a panel data approach for a set of the early European Union members, over the period 1980-2004. Conditional convergence is found between the EU countries, being reinforced when human capital, foreign trade and (non-price) competitiveness are controlled for in the growth model. In particular, our empirical results are encouraging, showing that human capital (especially at higher levels) and foreign trade (mostly through openness) or the interactions between them are all important determinants to growth. Important links were found between human capital, trade and economic growth supporting the idea of knowledge and technology diffusion. The hypotheses of export-led growth and balance-ofpayments constrained growth have also been highlighted in the empirical approach through the interaction between openness and competitiveness. The constraining element to growth may either be foreign trade, human capital, or both. Policy recommendation is self-explained from the empirical analysis, proposing improvements 
in human capital qualifications and developing innovation activities with the aim to turn the economies more competitive. 


\section{Appendix}

\section{Description of the variables and data sources}

- $y_{i, t}$ is real GDP per capita (Laspeyres), RGDPL - dollars in 2000 constant prices

- population - thousands of inhabitants

- $s_{i, t}$ is the investment share - percentage of GDPL in 2000 constant prices

- $o p_{i, t}$ is openness defined as exports plus imports to real GDP - percentage in 2000 constant prices

This data was collected from Heston et al. (2006), available at http://pwt.econ.upenn.edu/.

- $e d u c_{i, t}$ is the average years of education of population aged $25-64$, collected from Arnold et al. (2007).

- $\quad \operatorname{art}_{i, t}$, the articles ratio, is the number of articles published per million of inhabitants aged 25 or over (excluding papers from arts and humanities).

Data on the number of publications was collected from the Institute for Scientific Information (ISI) - Science Citation Index, available at http://isi15.isiknowledge.com. Data on the number of inhabitants aged 25 or over was collected from LABORSTA, Economically Active Population Estimates and Projections 1980-2020, Topic: Population and Economically Active Population (version 5), available at: http://laborsta.ilo.org/.

- pat $_{i, t}$, the patents ratio, is the number of patents per million of inhabitants aged 25 or over. The "utility patent" applications are registered on the residence of the first-named inventor.

Data on the number of patents was collected from the U.S. Patent and Trademark Office (USPTO), available at http://www.uspto.gov.

- pat $/ a r t_{i, t}$, the patents/articles ratio, was computed by the authors from the ratio between the number of patents and the number of publications.

- $n f b_{i, t}$, the net foreign balance, is the share of net exports of goods and services to real GDP and it was computed by the authors, subtracting from 100 the consumption, investment and government shares of RGDPL - percentage in 2000 constant prices. 
- $n_{i, t}+g+\delta$, the annual average growth rate of population, was computed by the authors from the population figures, to which was added 0.05 for the rate of technical progress plus capital depreciation as usually is assumed in growth empirical studies.

- $(\varepsilon / \pi)_{i, t}$, is the income-elasticity ratio of demand for exports and imports. The elasticity was computed by the authors, using the first difference of the logarithm of the variable of interest to compute the corresponding annual growth rate. The annual average growth rate was then computed for the following five-(four-) year intervals: 1976-1980, 19811985, 1986-1990, 1995-2000 and 2001-2004. Lastly, the ratio between the average growth rate of exports (imports) and external (internal) income provided us with the income-elasticity of demand for exports (imports) for the 6 time-intervals required for panel data estimation. The computation of the income-elasticity of demand for exports (and imports) thus required the previous calculation of the growth rate of the following variables:

$\mathrm{x}$ - Exports of goods and services in volume index $(2000=100)(\mathrm{OECD}, 2006 \mathrm{a})$

$z-$ GDP of OECD in volume index $(2000=100)($ OECD, 2006 b)

m - Imports of goods and services, volume index $(2000=100)(\mathrm{OECD}, 2006 \mathrm{a})$

$y$ - Country's real GDP, volume index $(2000=100)($ OECD, 2006 b) 


\section{References}

Abramovitz, M. (1986) Catching-up, forging ahead and falling behind, Journal of Economic History, XLVI, 2, 385-406.

Aghion, P.; Howitt, P. (1998) Endogenous growth theory, Cambridge, MIT Press.

Antunes, M.; Soukiazis, E. (2009) How well the balance-of- payments constraint approach explains the Portuguese growth performance. Empirical evidence for the 1965-2008 period., GEMF Working Paper 13/2009, FEUC.

Arellano, M.; Bond, S. (1991) Some tests of specification for panel data: Monte Carlo evidence and an application to employment equations, Review of Economic Studies, 58, 277-297.

Arellano, M; Bover, O. (1995) Another look at the instrumental variable estimation of errorcomponent models, Journal of Econometrics, 68, 29-51.

Arnold, J.; Bassanini, A.; Scarpetta, S. (2007) Solow or Lucas? Testing growth models using panel data from OECD countries, Economics Department Working Papers n. 592, OECD.

Atesoglu, H.S. (1995) An explanation of the slowdown in US economic growth, Applied Economic Letters, 2, 91-94.

Bairam, E. (1988) Balance-of-payments, the Harrod foreign trade multiplier and economic growth: the European and North American experience, 1970-1985, Applied Economics, 20, $1635-1642$.

Barro, R.; Sala-i-Martin, X. (2004) Economic growth, Cambridge, MIT Press (2 ${ }^{\text {nd }}$ edition).

Baum, C. (2006) An introduction to modern econometrics using Stata, College Station, Stata Press.

Benhabib, J; Spiegel, M. (2003) Human capital and technology diffusion, Working Papers in Applied Economic Theory, Federal Reserve Board of San Francisco,2003-02. 
Blundell, R.; Bond, S. (1998) Initial conditions and moment restrictions in dynamic panel data models, Journal of Econometrics, 87, 115-143.

Bond, S.; Hoeffler, A.; Temple, J. (2001) GMM estimation of empirical growth models, CEPR Discussion Papers n. 3048.

Borota, T.; Kutan, A. (2008) Regional integration and economic growth: the case of the European Union, The Journal of International Trade and Diplomacy, 2, 1, Spring, 93-113.

Button, K.; Pentecost, E. (1993) Regional service sector convergence, Regional Studies, 27, 623-636.

Caselli, F.; Esquivel, G; Lefort, F. (1996) Reopening the convergence debate: a new look at cross-country growth empirics, Journal of Economic Growth, 1, September.

Ciccone, A.; Papaioannou, E. (2006) Human capital, the structure of production and growth, Working Paper Series 623, European Central Bank, May.

Di Liberto, A. (2005) Convergence and divergence in neoclassical growth models with human capital, CRENoS Working Paper n. 8, Centre for North South Economic Research, Sardinia.

Economidou, C.; Lei, V.; Netz, J. (2006) International integration and growth: a further investigation on developing countries, International Advances in Economic Research, 12, 435448.

Garcimartín, C.; Rivas, L.; De Sarralde, S. (2008) Accounting for Irish growth: a balance-ofpayments-constraint approach, Journal of Post Keynesian Economics, 30, 3, Spring, 409-433.

Grossman, G.; Helpman, E. (1991) Innovation and growth in the global economy, Cambridge and Massachussets, MIT Press.

Harrison, A. (1991) A time series cross-country analysis for developing countries, Policy Research Working Paper Series $n^{\circ}$ 809, World Bank. 
Heston, A.; Summers, R.; Aten, B. (2006) Penn World Table Version 6.2, Center for International Comparisons of Production, Income and Prices at the University of Pennsylvania, September.

Islam, N. (1995) Growth empirics: A panel data approach, The Quarterly Journal of Economics, $1127-1171$

Kvedaras, V. (2006) Explanation of economic growth differences in the CEE countries: importance of the BOP constraint, Baltic Journal of Economics, 5, 2, 48-65.

Léon-Ledesma (1999) An application of Thirlwall's Law to the Spanish economy, Journal of Post Keynesian Economics, 21, 3, Spring, 431-439.

Levine, R.; Renelt, D. (1991) A sensitivity analysis of cross-country growth regressions, Policy Research Working Paper Series $n^{\circ}$ 609, World Bank.

Lucas, R. (1988) On the mechanisms of economic development, Journal of Monetary Economics, 22, 3-42.

Mankiw, G.; Romer, D.; Weil, D. (1992) A contribution to the empirics of economic growth, The Quarterly Journal of Economics, 407-437.

Marin, D. (1992) Is the export-led growth hypothesis valid for industrialized countries?, The Review of Economics and Statistics, 74, 678-688.

McCombie, J.S.L. (1997) On the empirics of balance-of-payments constrained growth, Journal of Post Keynesian Economics, 19, 3, Spring, 345-375.

Muscatelli, V.A.; Stevenson, A.A.; Montagna, C. (1994) Modeling aggregate manufactured exports for some Asian newly industrialized economies, The Review of Economics and Statistics, 77, 147-155.

Organization for Economic Co-operation and Development - OECD (2006 a) Statistical Compendium: General Economic Problems 1976-2004 
Organization for Economic Co-operation and Development - OECD (2006 b) Statistical Compendium: National Accounts and Historical Statistics 1976-2004.

Owen, A. (1999) International trade and the accumulation of human capital, Southern Economic Journal, 66, 1, 61-81.

Pacheco-López, P.; Thirlwall, A. (2006) Trade liberalization, the income elasticity of demand for imports, and growth in Latin America, Journal of Post Keynesian Economics, 2006, 29,1, Fall, 41-66.

Porcile, G.; Dutra, M.; Meirelles, A. (2007) Technology gap, real wages, and learning in a balance-of-payments constrained growth model, Journal of Post Keynesian Economics, 29, 3, Spring, 473-500.

Rodriguez, F.; Rodrik, D. (2000) Trade policy and economic growth: a skeptic's guide to the cross-national evidence, NBER Working Paper W7081, April.

Romer, P. (1986) Increasing returns and long-run growth, Journal of Political Economy, 94, 5, 1002-1037.

Roodman, D. (2006) How to do xtabond2: an introduction to "difference" and "system" in Stata, Center for Global Development Working Paper $n^{\circ}$ 103, December.

Sala-i-Martin, X. (2003) Convergence and divergence - theoretical underpinnings, in TumpelGugerell, G.; Mooslechner, P. (eds.) Economic convergence and divergence in Europe: growth and regional development in an enlarged European Union, Cheltenham, Edward Elgar.

Santos-Paulino, A.; Thirlwall, A. (2004) The impact of trade liberalisation on exports, imports, and the balance of payments of developing countries, The Economic Journal, 144, February, 5072.

Söderbom, M; Teal, F. (2003) Openness and human capital as sources of productivity growth: an empirical investigation, CSAE WPS/2003-06. 
Solow, R.M. (1956) A contribution to the theory of economic growth, Quarterly Journal of Economics, LXX, 65-94.

Soukiazis, E.; Cravo, T. (2008) Human capital and the convergence process among countries, Review of Development Economics, 12, 1, May, 124-142.

Thirlwall, A.P. (1979) The balance-of-payments constraint as an explanation of international growth rate differences, Banca Nazionale del Lavoro, 128, 45-53.

Thirlwall, A.P; Gibson, H. (1992) Balance-of-payments theory and the United Kingdom experience, $4^{\text {th }}$ Edition, Macmillan Press.

Turnvosky, S. (2001) Growth in an open economy: some recent developments, in Smets, J.; Dombrecht, M. (eds) How to promote economic growth in the Euro Area, Cheltenham, Edward Elgar.

Vera, L. (2006) The balance-of-payments-constrained growth model: a north-south approach, Journal of Post Keynesian Economics, 29, 1, Fall, 67-92. 
Table 1. Degree of openness and net foreign balance for the $14 \mathrm{EU}$ countries, 1980 and 2004

\begin{tabular}{|c|c|c|c|c|}
\cline { 2 - 5 } \multicolumn{1}{c|}{} & \multicolumn{2}{c|}{ Degree of openness (\%) } & \multicolumn{2}{c|}{ Net foreign balance (\%) } \\
\hline Country & $\mathbf{1 9 8 0}$ & $\mathbf{2 0 0 4}$ & $\mathbf{1 9 8 0}$ & $\mathbf{2 0 0 4}$ \\
\hline Austria & 57.461 & 102.948 & -2.964 & 3.976 \\
\hline Belgium & 104.360 & 173.987 & -1.403 & 4.204 \\
\hline Denmark & 48.588 & 94.516 & 1.804 & 4.686 \\
\hline Finland & 42.668 & 77.906 & -0.031 & 9.126 \\
\hline France & 31.622 & 57.467 & -1.008 & -0.795 \\
\hline Germany & 33.743 & 76.569 & -2.277 & 4.274 \\
\hline Greece & 28.111 & 54.260 & -0.417 & -10.060 \\
\hline Ireland & 65.101 & 176.668 & -9.312 & 18.047 \\
\hline Italy & 30.180 & 54.526 & 0.475 & -0.212 \\
\hline Netherlands & 77.730 & 146.847 & -1.101 & 6.757 \\
\hline Portugal & 35.612 & 79.891 & -3.081 & -9.959 \\
\hline Spain & 21.463 & 65.119 & 1.751 & -6.578 \\
\hline Sweden & 44.977 & 88.911 & -2.647 & 10.391 \\
\hline UK & 34.819 & 59.906 & 2.499 & -4.630 \\
\hline EU Average & $\mathbf{4 6 . 8 8 8}$ & $\mathbf{9 3 . 5 3 7}$ & $\mathbf{- 1 . 2 6 5}$ & $\mathbf{2 . 0 8 8}$ \\
\hline
\end{tabular}

Note on Table 1 and Charts 1 and 2: Source of the data is Heston et al. (2006). For description of variables, see the Appendix.

Chart 1. Degree of openness for the 14 EU countries, 1980 and 2004

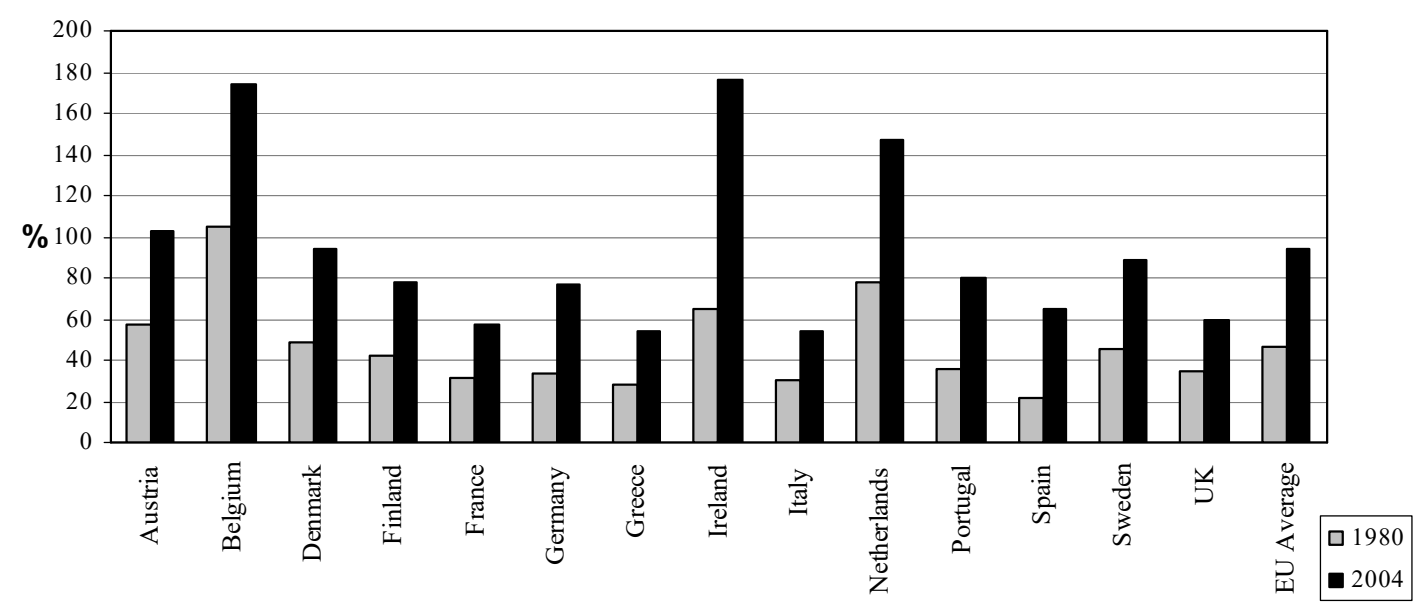


Chart 2. Net foreign balance for the 14 EU countries, 1980 and 2004

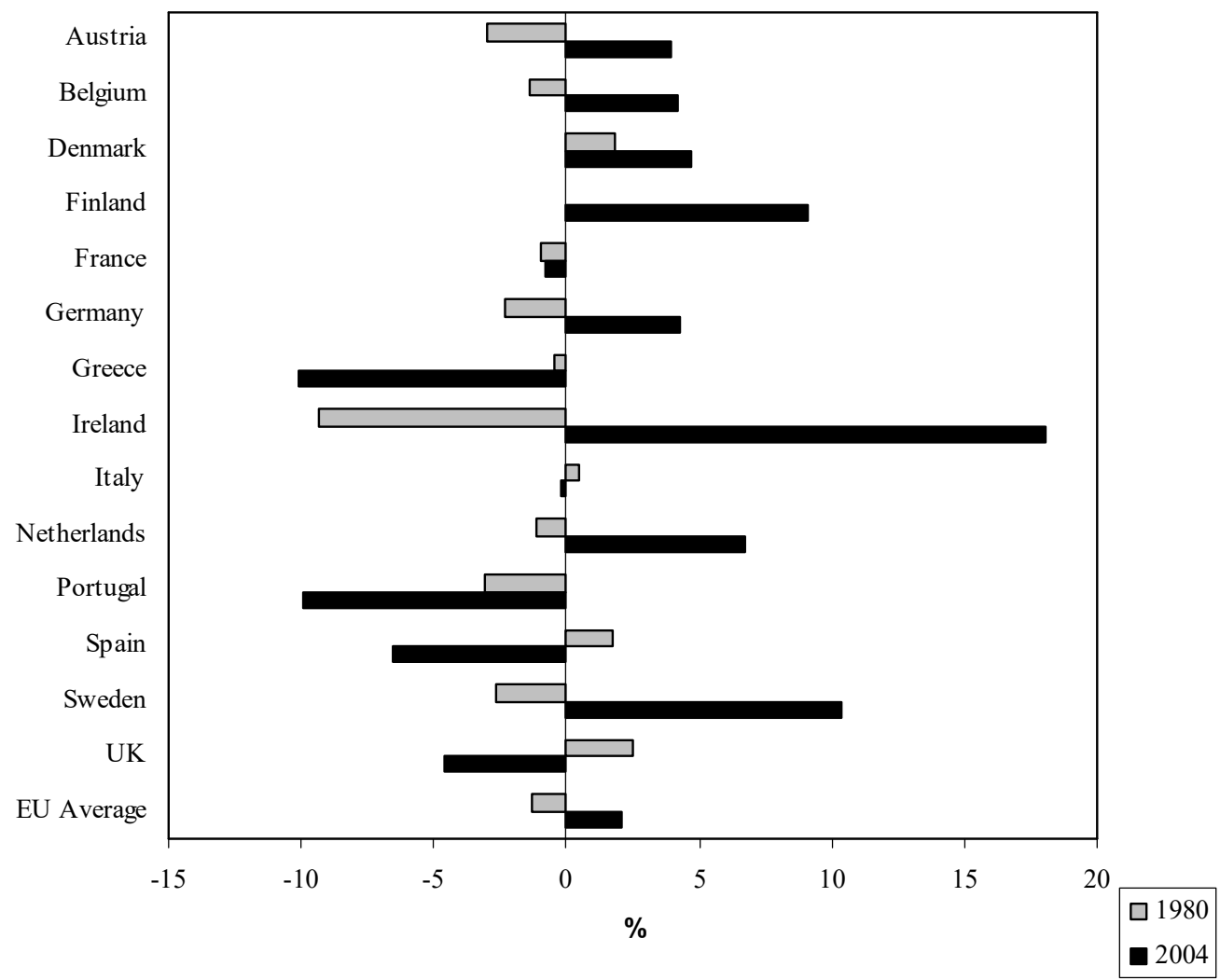

Chart 3. Income-elasticity ratio ( $\varepsilon / \pi)$ over five-year intervals, from 1976 to 2004

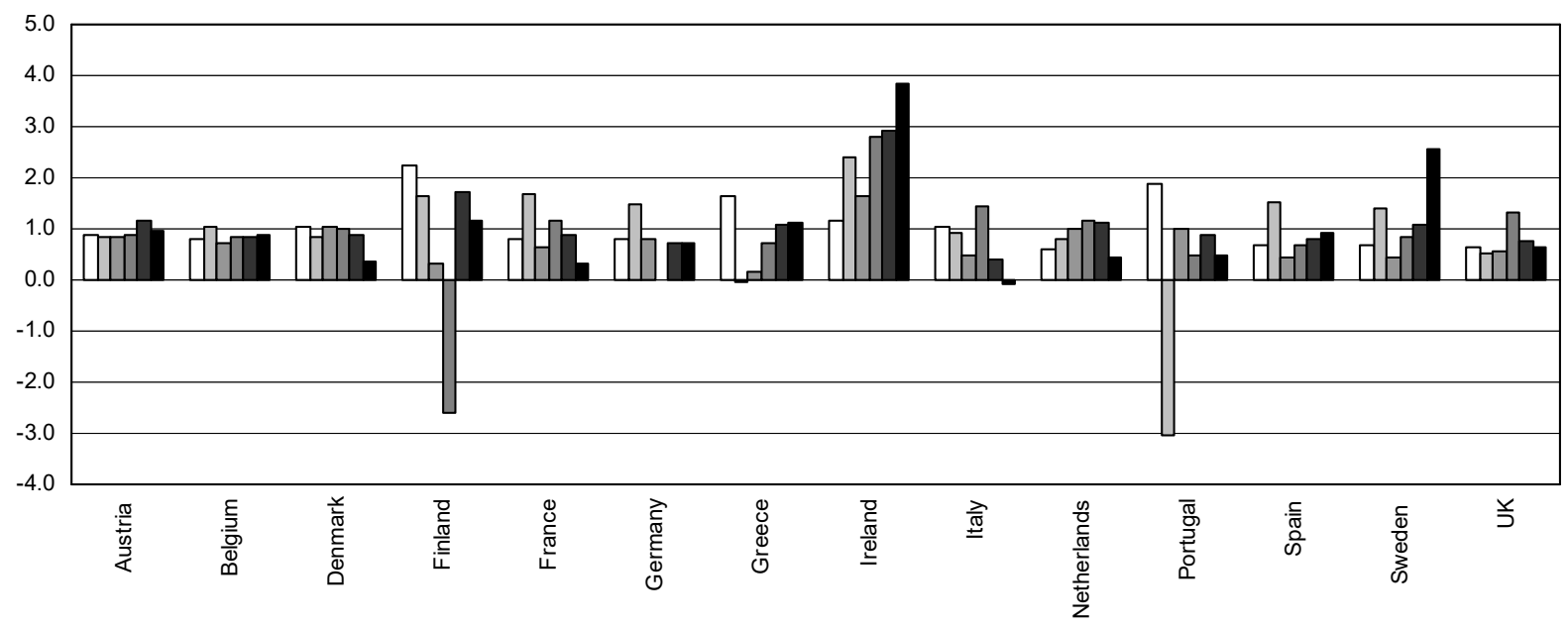

$\square(\varepsilon / \pi) 76-80 \square(\varepsilon / \pi) 81-85 \square(\varepsilon / \pi) 86-90 \square(\varepsilon / \pi) 91-95 \square(\varepsilon / \pi) 96-00 \square(\varepsilon / \pi) 01-04$ 
Table 2. Statistical data on human capital for the 14 EU countries, 1980 and 2004.

\begin{tabular}{|c|c|c|c|c|c|c|c|c|}
\cline { 2 - 9 } \multicolumn{1}{c|}{} & \multicolumn{2}{c|}{ educ } & \multicolumn{2}{c|}{ art } & \multicolumn{2}{c|}{ pat } & \multicolumn{2}{c|}{ pat/art } \\
\hline Country & $\mathbf{1 9 8 0}$ & $\mathbf{2 0 0 4}$ & $\mathbf{1 9 8 0}$ & $\mathbf{2 0 0 4}$ & $\mathbf{1 9 8 0}$ & $\mathbf{2 0 0 4}$ & $\mathbf{1 9 8 0}$ & $\mathbf{2 0 0 4}$ \\
\hline Austria & 10.4 & 12.4 & 526.1 & 1286.5 & 86.2 & 172.0 & 0.164 & 0.134 \\
\hline Belgium & 9.3 & 11.2 & 551.2 & 1457.5 & 62.0 & 178.5 & 0.113 & 0.122 \\
\hline Denmark & 10.6 & 11.7 & 925.2 & 2069.8 & 66.0 & 243.2 & 0.071 & 0.118 \\
\hline Finland & 9.5 & 12.0 & 754.5 & 1999.2 & 84.8 & 572.9 & 0.112 & 0.287 \\
\hline France & 9.5 & 11.0 & 655.1 & 1096.5 & 99.9 & 163.4 & 0.152 & 0.149 \\
\hline Germany & 11.4 & 12.8 & 589.2 & 1038.4 & 190.8 & 325.7 & 0.324 & 0.314 \\
\hline Greece & 7.9 & 10.7 & 118.6 & 790.0 & 3.7 & 7.7 & 0.031 & 0.010 \\
\hline Ireland & 8.5 & 10.8 & 728.8 & 1735.7 & 24.4 & 156.4 & 0.033 & 0.090 \\
\hline Italy & 7.3 & 9.9 & 235.2 & 792.1 & 42.6 & 67.8 & 0.181 & 0.086 \\
\hline Netherlands & 10.1 & 12.1 & 664.8 & 1658.3 & 120.1 & 269.5 & 0.181 & 0.162 \\
\hline Portugal & 7.2 & 8.1 & 32.5 & 636.2 & 1.3 & 4.0 & 0.039 & 0.006 \\
\hline Spain & 6.3 & 9.2 & 142.6 & 818.7 & 6.6 & 22.3 & 0.046 & 0.027 \\
\hline Sweden & 10.1 & 12.1 & 1028.1 & 2273.4 & 217.2 & 359.1 & 0.211 & 0.158 \\
\hline UK & 10.1 & 12.1 & 964.3 & 1628.0 & 117.2 & 188.4 & 0.122 & 0.116 \\
\hline EU Average & $\mathbf{9 . 2}$ & $\mathbf{1 1 . 2}$ & $\mathbf{5 6 5 . 4}$ & $\mathbf{1 3 7 7 . 2}$ & $\mathbf{8 0 . 2}$ & $\mathbf{1 9 5 . 1}$ & $\mathbf{0 . 1 2 7}$ & $\mathbf{0 . 1 2 7}$ \\
\hline
\end{tabular}

Notes:

educ is the average years of education of the population aged 25-64

art is the number of articles published per country's million inhabitants aged 25 or over pat is the number of patents per country's million inhabitants aged 25 or over 
Table 3. Panel data growth regressions for the 14 EU countries, 1980-2004

\begin{tabular}{|c|c|c|c|}
\hline Variables & (1) & (2) & (3) \\
\hline \multirow[t]{2}{*}{$\ln \left(\mathrm{y}_{\mathrm{i}, \mathrm{t}-5}\right)$} & $-0.1423 * * *$ & $-0.1638 * * *$ & $-0.1412 * * *$ \\
\hline & $(-5.29)$ & $(-4.99)$ & $(-4.76)$ \\
\hline \multirow[t]{2}{*}{$\ln \left(n_{i, t}+g+\delta\right)$} & 0.1071 & 0.1087 & -0.0452 \\
\hline & $(1.36)$ & $(0.91)$ & $(-0.41)$ \\
\hline \multirow[t]{2}{*}{$\ln \left(\mathrm{si}_{\mathrm{i}, \mathrm{t}}\right)$} & $0.0865^{* * *}$ & $0.1118^{* * *}$ & $0.0944 * * *$ \\
\hline & $(4.44)$ & $(3.59)$ & $(5.85)$ \\
\hline \multirow[t]{2}{*}{$\ln \left(\right.$ pat $\left./ \operatorname{art}_{\mathrm{i}, \mathrm{t}}\right)$} & $0.0426^{* * *}$ & & $0.0341 *$ \\
\hline & $(3.25)$ & & $(2.14)$ \\
\hline \multirow[t]{2}{*}{$\ln \left(\mathrm{op}_{\mathrm{i}, \mathrm{t}}\right)$} & $0.0777 * * *$ & $-0.2882 * *$ & $0.0596 * * *$ \\
\hline & $(4.64)$ & $(-2.16)$ & (3.03) \\
\hline \multirow[t]{2}{*}{$\ln \left(\right.$ educ $\left._{\mathrm{i}, \mathrm{t}}\right)$} & & $-0.5272 * *$ & \\
\hline & & $(-2.52)$ & \\
\hline \multirow[t]{2}{*}{$\ln \left(\mathrm{op}_{\mathrm{i}, \mathrm{t}}\right) * \ln \left(\mathrm{educ}_{\mathrm{i}, \mathrm{t}}\right)$} & & $0.1524 * *$ & \\
\hline & & $(2.76)$ & \\
\hline \multirow[t]{2}{*}{$(\varepsilon / \pi)_{\mathrm{i}, \mathrm{t}}$} & & & $-0.0820^{*}$ \\
\hline & & & $(-1.98)$ \\
\hline \multirow[t]{2}{*}{$\ln \left(\mathrm{op}_{\mathrm{i}, \mathrm{t}}\right)^{*}(\varepsilon / \pi)_{\mathrm{i}, \mathrm{t}}$} & & & $0.0225 * *$ \\
\hline & & & $(2.18)$ \\
\hline Observations & 56 & 56 & 56 \\
\hline Number of countries & 14 & 14 & 14 \\
\hline Number of instruments & 10 & 11 & 13 \\
\hline Hansen J-test & 3.562 & 5.370 & 5.977 \\
\hline$p$-value & 0.614 & 0.372 & 0.426 \\
\hline$A R 2$ & 0.429 & -0.589 & 0.241 \\
\hline p-value & 0.668 & 0.556 & 0.810 \\
\hline
\end{tabular}

\section{Notes:}

The dependent variable is the average annual growth rate of per capita income for each 5(4)-year interval.

Column (1) is two-step difference GMM estimations with robust standard errors, using the options "collapse" and "lag (1 2 )". 
$\overline{\text { Columns (2) and (3) are one-step difference GMM estimations with robust standard errors, using the }}$ options "collapse" and "lag (1 2)".

Numbers in brackets are t-ratio.

* Coefficient significant at the $10 \%$ level;** Coefficient significant at the $5 \%$ level; *** Coefficient significant at the $1 \%$ level.

Hansen J-test is the test of over-identifying restrictions in the GMM estimation.

$A R 2$ is the Arellano and Bond test for $2^{\text {nd }}$ order serial autocorrelation in first differences. 
Table 4. Panel data growth regressions for the 14 EU countries, 1980-2004. Additional results.

\begin{tabular}{|c|c|c|c|c|c|c|}
\hline Variables & (1) & (2) & (3) & (4) & (5) & (6) \\
\hline \multirow[t]{2}{*}{$\ln \left(\mathrm{y}_{\mathrm{i}, \mathrm{t}-\mathrm{5}}\right)$} & $-0.1100^{* * *}$ & $-0.1353 * * *$ & $-0.0889 * * *$ & $-0.1350 * * *$ & $-0.0493 * * *$ & $-0.0939 *$ \\
\hline & $(-3.65)$ & $(-5.78)$ & $(-3.16)$ & $(-5.13)$ & $(-3.11)$ & $(-1.76)$ \\
\hline \multirow[t]{2}{*}{$\ln \left(\mathrm{n}_{\mathrm{i}, \mathrm{t}}+\mathrm{g}+\delta\right)$} & $-0.2191 * *$ & 0.0463 & -0.0496 & 0.1074 & $-0.2558^{*}$ & $-0.3830 *$ \\
\hline & $(-2.39)$ & $(0.68)$ & $(-0.72)$ & (1.19) & $(-1.79)$ & $(-1.88)$ \\
\hline \multirow[t]{2}{*}{$\ln (s \mathrm{~s}, \mathrm{t})$} & $0.1104^{* * *}$ & $0.1229^{* * *}$ & $0.0952 * * *$ & $0.0900 * * *$ & $0.1303^{* * *}$ & $0.1035^{* *}$ \\
\hline & $(5.30)$ & $(9.24)$ & (3.64) & $(3.66)$ & $(4.53)$ & $(2.23)$ \\
\hline \multirow[t]{2}{*}{$\ln \left(\right.$ pat $\left._{\mathrm{i}, \mathrm{t}}\right)$} & $-0.0586^{* *}$ & $-0.0690 * * *$ & & & & \\
\hline & $(-2.76)$ & $(-3.49)$ & & & & \\
\hline \multirow{2}{*}{$\ln \left(\mathrm{op}_{\mathrm{i}, \mathrm{t}}\right) * \ln \left(\mathrm{pat}_{\mathrm{i}, \mathrm{t}}\right)$} & $0.0149 * *$ & $0.0169^{* * *}$ & & & & \\
\hline & $(2.95)$ & $(4.37)$ & & & & \\
\hline \multirow[t]{2}{*}{$\ln \left(\mathrm{op}_{\mathrm{i}, \mathrm{t}}\right)$} & & & $0.0511 * *$ & $0.0958 * * *$ & & \\
\hline & & & $(2.60)$ & $(4.37)$ & & \\
\hline \multirow[t]{2}{*}{$\ln \left(\mathrm{op}_{\mathrm{i}, \mathrm{t}}\right) * \ln \left(\right.$ pat $\left./ \operatorname{art}_{\mathrm{i}, \mathrm{t}}\right)$} & & & $0.0029 * * *$ & $0.0070 * *$ & & \\
\hline & & & $(3.44)$ & $(2.46)$ & & \\
\hline \multirow[t]{2}{*}{$(\varepsilon / \pi)_{i, t}$} & & & & & $-0.0953 * *$ & $-0.2487 * *$ \\
\hline & & & & & $(-2.50)$ & $(-2.19)$ \\
\hline \multirow[t]{2}{*}{$\ln \left(\mathrm{op}_{\mathrm{i}, \mathrm{t}}\right) *(\varepsilon / \pi)_{\mathrm{i}, \mathrm{t}}$} & & & & & $0.0237 * *$ & $0.0632 * *$ \\
\hline & & & & & $(2.68)$ & $(2.21)$ \\
\hline \multirow[t]{2}{*}{ Constant } & 0.0947 & & 0.2720 & & -0.6533 & \\
\hline & $(0.44)$ & & $(1.04)$ & & $(-1.17)$ & \\
\hline Observations & 70 & 56 & 70 & 56 & 70 & 56 \\
\hline Number of countries & 14 & 14 & 14 & 14 & 14 & 14 \\
\hline Number of instruments & 10 & 9 & 10 & 9 & 10 & 9 \\
\hline Hansen J-test & 4.827 & 3.308 & 5.722 & 5.005 & 6.638 & 2.301 \\
\hline$p$-value & 0.306 & 0.508 & 0.221 & 0.287 & 0.156 & 0.681 \\
\hline$A R 2$ & -0.855 & 0.528 & 1.248 & 0.126 & -1.593 & -1.007 \\
\hline$p$-value & 0.393 & 0.598 & 0.212 & 0.900 & 0.111 & 0.314 \\
\hline
\end{tabular}

Notes:

Columns (1), (3) and (5) are two-step system GMM estimations with robust standard errors, using the options "collapse" and "lag (1 1)". 
Columns (2) and (6) are one-step difference GMM estimations with robust standard errors, using the options "collapse" and "lag (1 2 )".

Column (4) is two-step difference GMM estimations with robust standard errors, using the options "collapse" and "lag (1 2 )".

For further notes - see Table 3. 